
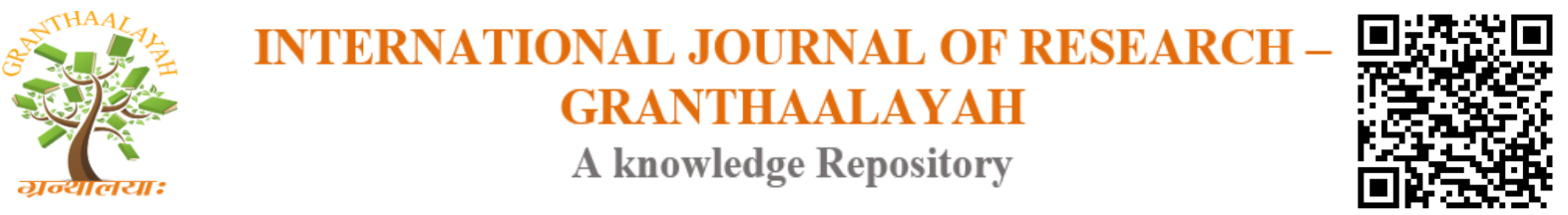

Science

\title{
A SYSTEMATIC REVIEW TO ASSESS THE EFFECTIVENESS OF WEB BASED TRAINING VIDEO FOR LAPAROSCOPY SURGERY
}

\author{
Alfred Egedovo ${ }^{1,2}$, Yik-Hong Ho ${ }^{1,3}$, Sarah Larkins ${ }^{1}$, Chrispen Mushuya ${ }^{3}$ \\ ${ }^{1}$ College of Medicine and Dentistry, James Cook University, James Cook Drive, Douglas, \\ Townsville, QLD 4811, Australia \\ ${ }^{2}$ Public Health and Tropical Medicine, College of Public Health, Medical and Veterinary \\ Studies, James Cook University, Townsville, QLD 4811, Australia \\ ${ }^{3}$ Department of Surgery, The Townsville Hospital, Townsville, QLD 4814, Australia
}

\begin{abstract}
Background: Surgical training for generations has followed the example of an apprenticeship model propagated by William Halsted; teaching method of "see one, do one, teach one". Teaching of surgical trainee is time consuming and costly in the operating room when it involves a procedure, ${ }^{4,5}$ and the surgical skills acquired from operating room are of variable effectiveness because of the learning curve. ${ }^{6,7}$

The objective of this review is to determine if web-based training video (WBTV) is effective to supplement and /or replace the standard surgical training model (SLT). However, the value of this modality for trainees with or no laparoscopic experience is unknown.

Study Hypothesis: Multimedia or Web-based training video (WBTV) learning is equivalent to conventional teaching (Standard surgical training-SLT) in improving scores in cognitive surgical skills.

Search Method: Randomized clinical trials addressing this issue were identified from The Cochrane Library trials register, Medline, Embase, Science Citation Index Expanded, grey literature and reference lists and other databases. The Cochrane Central Register of Controlled Trials: search was narrowed to Issue of 6 of 12, June 2014. Included studies were randomized controlled trials (RCTs) assessing any training technique using at least some elements of surgical simulation, which reported measures of surgical task performance. The Cochrane search yielded one relevant article. $^{8}$ In the MEDLINE search, the medical Subject Heading (MeSH) was used to search for; Surgical stimulation, surgical training, "Web-based training" and "online education or teaching, training, internet, multimedia teaching" (retrieved articles 78, relevant articles 50) and the headings "Laparoscopy" and "education" (retrieved 103, relevant 91) other provisional abstract (review 3). I focused the search on articles published from 1990 onwards, and I limited it to articles published in English. I did not include case reports and data from abstracts in data synthesis. All of the identified articles were examined for relevance. Retrieved studies were screened for duplication, and additional studies were identified using a manual search of the reference list of the relevant included articles. Since my review focused on Web-based training video effectiveness for teaching laparoscopic surgery techniques, my search strategies was limited to identifying articles focusing on surgical education.
\end{abstract}


Selection Criteria: I included all randomised clinical trials comparing Web-based model trainers versus other forms of training including standard laparoscopic training and supplementary animal model training use for teaching surgical trainees with or no laparoscopic experience. I also included trials comparing different methods of simulation surgical training.

Results: Thirty RCTs with 831 participants were included, although the quality of the RCTs was often poor. The Web-based training video (WBTV) had one RCTs, the RCT had four intervention groups, they were groups multimedia (WBTV) training, Practical Training (Standard training, Multimedia (WBTV) plus practical training and none of the trainings had different skills but all participants were homogeneous with the same basic skills on laparoscopic cholecystectomy. The result was that multimedia - based (WBTV) training improved surgical performance of Laparoscopic cholecystectomy in a pelvic -trainer significantly when used alone or as combination training. While Virtual reality simulation had shown better results than no training at all, but had no evidence of superiority over standard training practised. When it is done purposefully or video box simulation based on operative performance. Video simulation did not show consistently better results than groups with no training at all, and there were not enough data to determine if video simulation was better than standard training or the use of models. Model simulation may have been better than standard training. Two trials (mostly with a high risk of bias) involving 110 participants were included in this review. In trainees without surgical experience, WBTV training decreased the time taken to complete a task, increased accuracy and decreased errors compared with no training. In the same participants, WBTV training was more accurate than Standard practical training. In participants with laparoscopic experience practical training plus Web-based video training, WBTV training resulted in a greater reduction in operating time, error and unnecessary movements than standard laparoscopic training. In these participants, the composite performance score was better in the WBTV group than the practical group (standard).

Conclusion: WBTV can supplement standard surgical training. However the quality is poor, It is at least as effective as no standard training in supplementing standard laparoscopic training. While there may be compelling reasons to reduce reliance on patients, cadavers, and animals for surgical training, none of the methods of simulated training has yet been shown to be better than other forms of surgical training.

Keywords: Web Based Training Video; Laparoscopy Surgery; Surgical Training.

Cite This Article: Alfred Egedovo, Yik-Hong Ho, Sarah Larkins, and Chrispen Mushuya. (2017). "A SYSTEMATIC REVIEW TO ASSESS THE EFFECTIVENESS OF WEB BASED TRAINING VIDEO FOR LAPAROSCOPY SURGERY." International Journal of Research - Granthaalayah, 5(10), 270-289. https://doi.org/10.29121/granthaalayah.v5.i10.2017.2304.

\section{Introduction}

Traditionally surgery has always been taught through 2D anatomy in medical school which is gained in form of lectures, PowerPoint presentations and videos in class. But over 500 years ago it shift to 3D training involving using cadavers. ${ }^{9}$ Surgical trainees were educated through the years, the method "see one, do one, teach one", where the surgical trainee learns to perform surgery under the supervision of a trained surgeon. ${ }^{1-3}$ Surgical procedures are affected by learning curve problem because various operations have different learning curve. ${ }^{6,7}$. 
Conventional surgery or open also is affected with Surgeon variants in experience because a surgeon with certain experience may lack the other and this lead to the desire to improve. The drive to achieve improved patient outcomes and patient safety has led to innovation in surgical education.

Because complete open surgeries are complex to copy or simulate, surgical procedures are complex motion sequences that require a high level of preparation, training, and concentration. Only with the acceptance of laparoscopic surgery into regular surgical practice, did innovators started creating multimedia-based (WBTV) in internet platform modelling the video image seen by surgeons doing laparoscopy and used as a surgical training technique. ${ }^{8}$

The various techniques of laparoscopic surgical training include live animal training, human and animal cadaver training, training using a box trainer (also called a video trainer, VT), Webbased training video (also called multimedia, E-learning, Computer-assisted learning or regarded as other resources using recorded laparoscopic surgery for learning, and also called Observational Learning on Surgical performance ${ }^{10}$ ) and virtual reality (VR) training (training using computer simulation). ${ }^{11}$ WBTV is currently being used widely for laparoscopic training ${ }^{12-}$ 15 and has been shown to be better than standard training. ${ }^{8,16}$ WBTV training has been reported to improve learning outcomes in different surgical procedures ${ }^{8,10,12,16,17}$. It also offers an ethical way of assessing the competency of a surgeon in performing a procedure, after using WBTV without risk to a patient.

Web-based training videos for Laparoscopic Surgery are developed from live recorded laparoscopic procedures at operating theatres. The videos are customized and formatted with instructor support ${ }^{18}$ To improve surgical skills, different simulation training are used such as Virtual reality (VR) and practical training in lab training, didactic lectures are used and most cases surgical trainees refer to their book for surgical manuals which is time consuming and updating difficulties of the print apply. It is easy updating videos on the internet compare to the long process of publication. Surgical simulation techniques available like VR is very expensive about cost (\$120000). VR has been validated to be of effective value compare to other techniques ${ }^{19-23}$ and the training a resident and time taken to complete an instruction during a surgical procedure based on cost value is $(\$ 12,000)$ per year. ${ }^{4,24}$ The internet plat form has created a better alternative to learning Laparoscopic skills because it cheaper, unlike Websurg charges user $\$ 14.95$ per video ${ }^{12}$ and a WBTV is easily accessible, current, convenient can be access anytime from home and office ${ }^{8,12,16,25}$ and effectiveness is assumed to be better than standard practical training. ${ }^{8}{ }^{26}$ However, the effect of Web-based training video on practical surgical skills has not yet been evaluated; there is paucity of data about its value. This study aimed to evaluate the effectiveness of Web-based training with laparoscopic or no laparoscopic experience to supplement or/replace standard surgical training. Though there was one selected article to be relevant from The Cochrane HepatoBiliary Group Controlled Trials Register, the Cochrane Central Register of Controlled Trials (CENTRAL). The Web-based training video technique has a gap of knowledge compare to the voluminous papers that have been published in support of the other methods of teaching Laparoscopic Surgery. ${ }^{27-33}$

Schreduder et als ${ }^{13}$ stated in his article; that traditional classroom problem-based learning can be transferred to a virtual environment, like in Second Life, thus enabling a modern yet familiar 
environment for problem-based learning (Conradi et al. 2009). Besides, Schreduder article is in line with the publication of Didier et als ${ }^{12}$ articles that assess the impact of Web-based application World Electronic Book of Surgery (WebSurg). His study which was based on the analysis from a Web-based laparoscopic learning site concluded that the (WebSurg) are widely used in the surgical community. The website based training enhances but the consideration of ethical principles of accreditation of scientific societies is important. The result from the study was obtained by using software to monitor of all that visited the WebSurg from the different surgical field and what they accessed from different languages 5 different languages, namely, English, French, Spanish, Japanese, and Chinese. WeBSurg is made up of files totaling 260 gigabytes of data (videos, pictures, Flash animations, scripts, text files, etc.). The Limelight Networks' CDN (content delivery network) is used to display and broadcast its contents all over the world it was seen that between 2004 and 2010, the number of visitors, members, active members, and video hits show an impressive development. In September 2010, WeBSurg gathered more than 202000 members. Of these, 60\% are fellows and young surgeons aged between 28 and 34 years. The age distribution demonstrates that the Web site responds to a wide range of surgical experience. Worldwide coverage is confirmed by an analysis of the geographic distribution of its members. From September 1, 2009 to September 1, 2010, WeBSurg recorded a total of 1396784 visitors originating from 213 countries or territories. Of which Australia; No. of Visits 12 468, Pages/Visit, 4.7, Average Time on Site (min) 5.7, Percentage New Visits 51. Which infer Australia surgical trainee and surgeon have access and Queensland surgical trainees as it would be applicable to the purpose of this review. Because of my scope of study other countries visit rate was not included. During this period, Limelight transmitted 17670 gigabytes (17.25 terabytes) of video data. Limelight control report also enables to learn about the video connection length equalling a total of 3716 days (i.e. 10.2 years).

Online web-based learning portal for teaching laparoscopic surgery has become very popular and contains a large collection of streaming and downloadable HD quality videos of surgical procedures, combined with how-to step-by-step surgical teaching guidelines to aid the implementation of laparoscopic surgical procedures for various surgical disciplines. ${ }^{12,13}$ According to Schreduder et. als ${ }^{13}$ there has been advancement to bring to validation the WBTV because recently the first interactive e-learning program for laparoscopy was introduced ${ }^{13}$. This is called "SimpraxisTM Laparoscopic Cholecystectomy Trainer" a customizable interactive simulation software training platform for cognitive learning of surgical procedures. The technology integrates multimedia (such as video, 3D models, radiology, illustrations, text, and still images, all captured from live procedures) and combines them with expert cognitive training pedagogy to create a powerful simulation of the procedure. All these elements combined simulate the feeling of performing the actual physical procedure while only using a computer.

The web-based training video used for learning laparoscopic surgery is one of the various techniques for teaching laparoscopic surgery. However, no clear evidence of the superiority of one over the other in skill acquisition. But there are arguments that it has some educational value though more studies should be completed to evaluate it validity and added value compare to other surgical training techniques. From a systematic review, concluded that simulation-based training is more effective than video-based instruction ${ }^{34}$ 
However, three major classes of surgical simulators are recognised.27 Reality-based simulators are ones in which the learner interacts with solid, real life materials and uses surgical instruments expected to be used in the operating room. E.g.:

Fundamentals of Laparoscopic (FLS) Box trainer (VT) ${ }^{35-37.30,38-40}$ (also Called Video trainer)

A program of the society of America Gastrointestinal and Endoscopic Surgeons (SAGES) and the American College of Surgeon (ACS). ${ }^{41}$ Image see below.

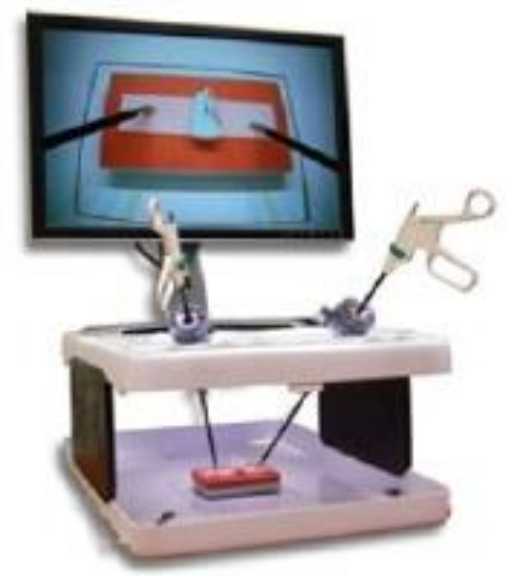

Figure 1: FLS Box Trainer by FLS ${ }^{42}$ and VTI Medical

\section{Web-based Training Video (WBTV) ${ }^{8,12,16,17,43,44}$}

Web-based simulation allows learners to interact with online curricula, exercising the cognitive aspects of surgery (e.g., what are the steps of a gallbladder removal, what surgical instruments are needed). Internet platforms providing surgical content have been established. Used as a surgical training method, the effect of multimedia-based training on practical surgical skills has not yet been evaluated. This study aimed to evaluate the effect of multimedia-based training on surgical performance. ${ }^{8}$
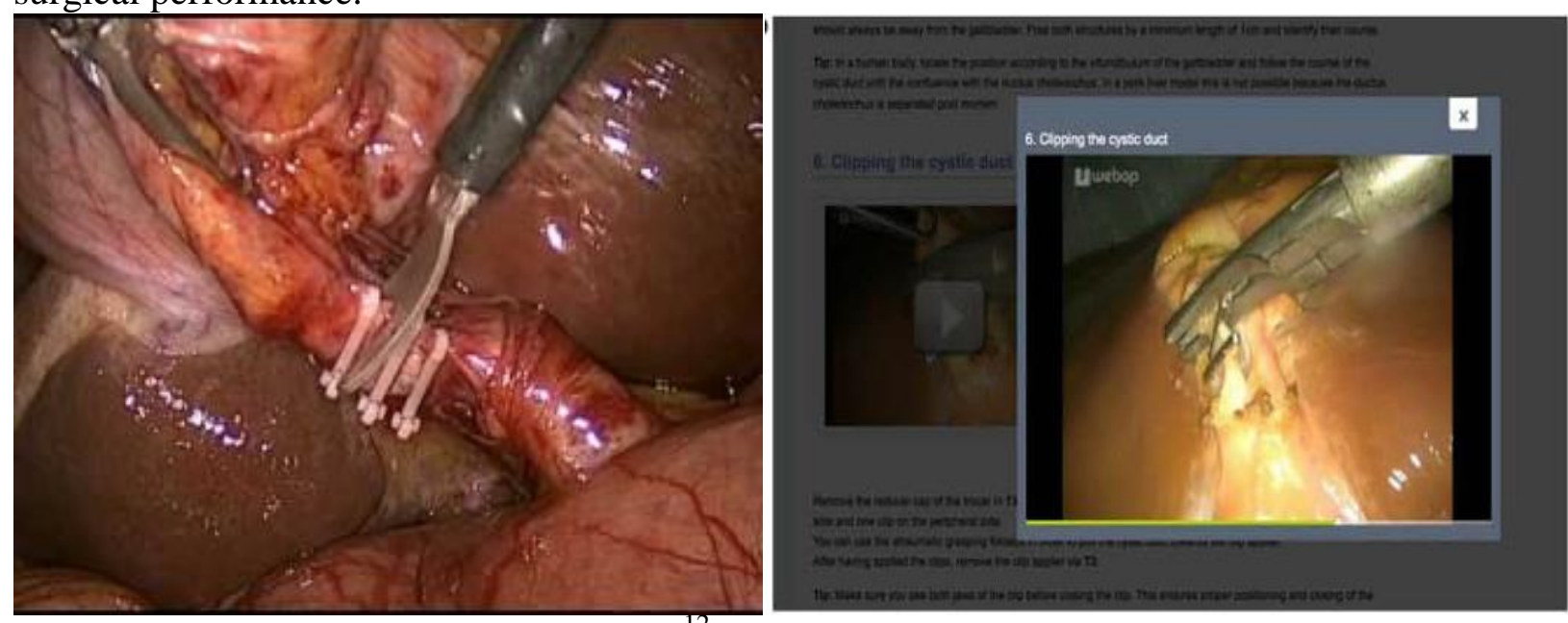

Figure 2: Screenshot of a WeBsurgery ${ }^{12}$ high-definition video - Web-based training Video

(WBTV) Model 


\section{Virtual Reality simulator (VR) ${ }^{40,45-48}$}

The most technologically sophisticated class of simulator is the VR simulator, which features a computer-generated model of anatomy and requires that learner use near similar instrumentation to interact with virtual tissue structures and models

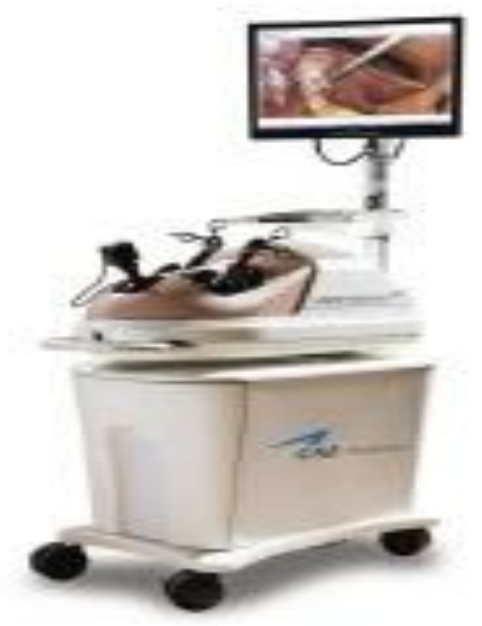

Figure 3: CAE Laparoscopy VR surgical simulator

Laparoscopic surgery has influence surgical practice rapidly since its acceptance in the eighties and patients prefer Laparoscopic surgery to the traditional open surgery. Laparoscopic Surgical procedure is preferred because of the short stay in hospital, small incision and low incidence of complications. But the teaching of laparoscopic surgical skills is challenging, because of the complexities around the instruction and the different techniques of teaching skills. Thus laparoscopic surgery introduction had evolving barriers there is a need for good knowledge of anatomical structure which is crucial. Surgeons identify anatomical structure from screen because of this tactile feedback and spatial oriental is reduced. An additional challenge associated is gradual learning curve which had created the need for effective teaching mode.

\section{Objective}

The selection of trial studies and data extraction was only randomized clinical trials regardless of the language. And assessment was targeted for effectiveness of Web-based training video (WBTV) compared with or no training or standard laparoscopic training (SLT) (irrespective of generic skills or procedure-specific skills) were included in the review.

\subsection{Method and Literature Search Strategy}

All randomized controlled trials (RCTs) and nonrandomized comparative studies (non-RCTs) reporting on the use of different techniques for learning Laparoscopic Surgery and the transfer of these skills to the operative setting were included for review. The literature search was performed in MEDLINE, EMBASE, CINAHL, PubMed, the Cochrane Library and Current Contents databases that was update until June 2014 and science citation index expended. ${ }^{49}$ The Cochrane Library 2014, Issue $3^{37}$ was check to see changes, I searched the Clinical Trials 
Database (US), the NHS Centre for Research and Dissemination Databases (UK), the National Research Register (UK), the Meta Register of Controlled Trials (SRCTN) and the Australian New Zealand Clinical Trials Registry, last data file imported on 14 July 2014 and using the Cochrane strategies. ${ }^{49}$ And the clinical trial information via the World Health Organization (WHO) search portal (ICTRP search portal) Searches were conducted without language restrictions. The search terms used were (surg* and simulat*) and (skill* or train*). Scanning of Literature was then undertaken to locate articles that may have been missed by the electronic database searches. MeSH terms were used and searched for (Therapy, Computer-Assisted OR Surgery, Computer-Assisted OR Computer-Assisted Instruction), free-text terms ( Web-based* internet* Multimedia, online* OR simulat*) combined with the terms 'train' and 'laparoscopy' (MeSH term and equivalent free-text search terms). A filter for identifying the randomized controlled trials recommended by The Cochrane Collaboration ${ }^{50}$ was used to filter out nonrandomized studies in Medline and Embase. In addition to the databases, SCOPUS, education indexes (ERIC Education Resources Information Center, Australian Education Index (replace by Informit), and British Education Index (Replace EBSCO Information services), computer databases (ACM Digital Library, collection of Computer Science Bibliographies, IEEE/IEE Electronic Library), Meta-register of Controlled Trials and Google Scholar were searched. Grey literature, abstracts and conference proceedings were identified by searching the ISI proceedings, Zetoc General Search (this needed a password to access), 'index to thesis', GrayLIT Network (replaced by Science.gov), abstracts from AMED(Allied and Complementary Medicine Database), biological abstracts, biotechnology abstracts, British Nursing Index, dissertation abstracts (American institutions) and SIGLE (grey literature in EC member countries and held at The British Library). References of the identified trials were also searched to identify further relevant trials. I identified the trials for inclusion and extracted the data related to first author, year of publication, inclusion and exclusion criteria, participant characteristics, details of training such as software used, tasks in training, duration of training, outcomes of interest, methodological quality of the studies (without masking the study names), whether intention-totreat analysis was followed and whether sample size calculations were reported.

This systematic review was limited to the literature relating to surgical education. The comprehensive Australian Safety and Efficacy Register of New Interventional ProceduresSurgical reports 613 and 80, 4 which include additional procedures investigated, which could be found online at http://www.surgeons.org/asernip-s/. And a details review report on surgical simulation was studied and analysed for update issues on laparoscopic surgical education and surgical training in Australia.

\section{Data Extraction and Analysis}

Data from all included studies were extracted by me and checked for standardized data extraction tables developed a priori. Each included study was critically appraised for its study quality and assigned a level of evidence according to the hierarchy of evidence developed by the National Health and Medical Research Council of Australia. ${ }^{51}$ Study quality was assessed according to the methods given in of the Cochrane Reviewers' Handbook ${ }^{50}$ on a number of parameters, including quality of the reporting of study methodology, methods of randomization and allocation concealment (for RCTs), blinding of trainers and outcomes assessors, and sample sizes. It was judged that no data were suitable for statistical pooling due to the heterogeneity of the results. 


\section{Outcomes}

Data for the following outcomes were extracted: patient or animal mortality or morbidity (reported separately in trials where both patients and animals were used for assessing outcome measures); time taken to perform the evaluation task on the simulation model (after training); operating time (if the evaluation task was performed on humans or animals) (after training); error score: the number of undesirable movements, for example, injury to gallbladder or burning nontarget tissue; accuracy; improvement in task performance (objective or subjective); and participant satisfaction. Definitions or scales used by the authors were accepted for the various outcomes.

\subsection{Assessment of Methodological Quality}

\section{Inclusion Criteria}

Only studies pertaining to Laparoscopic surgical education methods are included in this review. Included studies had to report on effectiveness of training techniques and the impact should have a benefit measure of task performance in the operative setting including global rating score, pass/fail score, time to complete task/procedure.

\section{Hierarchy of Evidence Checklist ${ }^{52}$}

\begin{tabular}{|c|c|c|}
\hline \multirow{2}{*}{$\begin{array}{l}\text { Level } \\
1\end{array}$} & & Study Type \\
\hline & A & Systematic review ( with homogeneity) of randomised controlled trials \\
\hline \multirow{4}{*}{2} & $\mathrm{~B}$ & Individual randomised controlled trail with narrow confidence interval \\
\hline & $\mathrm{C}$ & All or None \\
\hline & A & Systematic review ( with homogeneity) of cohort studies \\
\hline & $\mathrm{B}$ & $\begin{array}{l}\text { Individual cohort study (including low quality randomised controlled } \\
\text { trials) }\end{array}$ \\
\hline \multirow{3}{*}{3} & $\mathrm{C}$ & "Outcomes" research; Ecological studies \\
\hline & A & Systematic review ( with homogeneity) of case-control studies \\
\hline & $\mathrm{B}$ & Individual case- control study \\
\hline 4 & & Case series ( and poor quality cohort and case-control studies) \\
\hline 5 & & Expert opinion without explicit critical appraisal \\
\hline
\end{tabular}

Article Selection rating

\begin{tabular}{|l|l|l|l|l|l|l|l|l|l|l|l|}
\hline & 1 & 2 & 3 & 4 & 5 & 6 & 7 & 8 & 9 & & \\
\hline Quantitative & & & & & & & & & & \\
\hline Non-clinical, Non-laparoscopic surgery & & & & 3 & & & & & & \\
\hline Clinical Non-laparoscopic surgery & & & 5 & & & & & & & & \\
\hline Non-clinical Laparoscopic Surgery & 1 & & & & & & & & & & \\
\hline Qualitative & & & & & & & & & & & \\
\hline Clinical Non-Laparoscopic Surgery & & & 1 & & & & & & & & \\
\hline Non-clinical Laparoscopic Surgery & 4 & & & & & & & & & & \\
\hline
\end{tabular}

The order of exclusion criteria for article selection

1) Unable to obtain full text

2) Articles published before 1990 . 
3) Subjects unrelated to a medical profession

4) Articles which examined same-year peer review and assisted learning

5) Non-experimental design

Selected literature reviewed for WBTV outcome - Hierarchy of Evidence

\begin{tabular}{|c|c|c|c|c|c|}
\hline Authors & Participants & $\begin{array}{c}\text { Evidence } \\
\text { Level }\end{array}$ & $\begin{array}{c}\text { Interventio } \\
\mathbf{n}\end{array}$ & $\begin{array}{l}\text { Outcome } \\
\text { Measure }\end{array}$ & Results \\
\hline $\begin{array}{l}\text { Pape-koehler } \\
\text { et als }(2013)^{8} \\
\text { Germany }\end{array}$ & $\begin{array}{l}\text { Subjects; general } \\
\text { surgeons and } \\
\text { surgery resident } \\
\text { and medical } \\
\text { students }\end{array}$ & RCT 1a & $\begin{array}{l}\text { Surgical } \\
\text { performance } \\
\text { multimedia }\end{array}$ & $\begin{array}{l}\text { Task specific } \\
\text { and cognitive } \\
\text { skill }\end{array}$ & $\begin{array}{l}\Delta \text { OSATS results } \\
\text { were highest in the } \\
\text { Multimedia-based } \\
\text { training group ( } 4.7 \\
\pm 3.3 \text {;p }(0.001) \text {. }\end{array}$ \\
\hline $\begin{array}{l}\text { Adams et als } \\
(2002)^{16} \\
\text { USA }\end{array}$ & $\begin{array}{l}\text { General surgeons, } \\
\text { surgery residents } \\
\text { medical } \\
\text { Student }\end{array}$ & $\mathrm{RCT} 1 \mathrm{~b}$ & Multimedia & $\begin{array}{l}\text { Cognitive } \\
\text { skills }\end{array}$ & $\begin{array}{l}\text { Experimental } \\
\text { Group was found } \\
\text { to have } \\
\text { statistically } \\
\text { improved more } \\
\text { than the Control } \\
\text { Group }(\mathrm{p}=.023)\end{array}$ \\
\hline $\begin{array}{l}\text { Snyder et als } \\
(2010)^{10} \\
\text { USA }\end{array}$ & Medical students & RCT 1a & multimedia & $\begin{array}{l}\text { Improve } \\
\text { performance } \\
\text { compare to } \\
\text { standard }\end{array}$ & $\begin{array}{l}\text { independent } \\
\text { versus preceptor } \\
\text { training [Hazard } \\
\text { Ratio (HR) } \\
1.28 ; 95 \% \\
\text { Confidence } \\
\text { Interval (CI) } 0.96- \\
1.72 ; \mathrm{p}=0.09 \text { ]. }\end{array}$ \\
\hline $\begin{array}{l}\text { Carla et als } \\
(2009) \\
\text { USA }\end{array}$ & $\begin{array}{l}\text { Surgical } \\
\text { professionals }\end{array}$ & $4 \mathrm{a}$ & $\begin{array}{l}\text { Tech. } \\
\text { advance, } \\
\text { political, } \\
\text { internet }\end{array}$ & $\begin{array}{l}\text { Surgical } \\
\text { education }\end{array}$ & $\begin{array}{l}\text { Challenges and } \\
\text { reward }\end{array}$ \\
\hline $\begin{array}{l}\text { Tolerton et als } \\
(2012 \\
\text { Australia }\end{array}$ & $\begin{array}{l}\text { WBTV Creator and } \\
\text { viewer }\end{array}$ & $\mathrm{RCT} 2 \mathrm{~b}$ & $\begin{array}{l}\text { Audio- } \\
\text { visuals } \\
\text { learning }\end{array}$ & $\begin{array}{l}\text { Surgical } \\
\text { training }\end{array}$ & $\begin{array}{l}\text { Teaching tool for } \\
\text { laparoscopic } \\
\text { cholecystectomy }\end{array}$ \\
\hline $\begin{array}{l}\text { Didier et als } \\
(2011) \\
\text { France }\end{array}$ & $\begin{array}{l}\text { Surgeons, trainees } \\
\& \text { others }\end{array}$ & $3 c$ & $\begin{array}{l}\text { Multimedia, } \\
\text { WebSurg }\end{array}$ & $\begin{array}{l}\text { Surgical } \\
\text { performance } \\
\text { awareness }\end{array}$ & $\begin{array}{l}\text { High percentage of } \\
\text { WBTV users } \\
\text { Reduce cost }\end{array}$ \\
\hline $\begin{array}{l}\text { Fraser et als } \\
(2011) \\
\text { UK }\end{array}$ & Otolaryngologist & $4 d$ & E-learning & awareness & $\begin{array}{l}\text { Variable website, } \\
\text { receptive to free, } \\
\text { otolaryngology e- } \\
\text { learning }\end{array}$ \\
\hline $\begin{array}{l}\text { Umar et als } \\
\text { Study } \\
\text { completed } \\
\text { Clinicaltrials.g } \\
\text { ov. } \\
\text { Ncto1866436 } \\
(2012) \\
\text { UK }\end{array}$ & $\begin{array}{l}\text { PG general surgical } \\
\text { trainees, specialist } \\
\text { year3 registrar year } \\
\text { or above }\end{array}$ & $1 \mathrm{a}$ & $\begin{array}{l}\text { Multimedia } \\
\text { group } \\
\text { Study day } \\
\text { group }\end{array}$ & $\begin{array}{l}\text { Cognitive } \\
\text { surgical skill } \\
\text { acquisition }\end{array}$ & effective \\
\hline
\end{tabular}




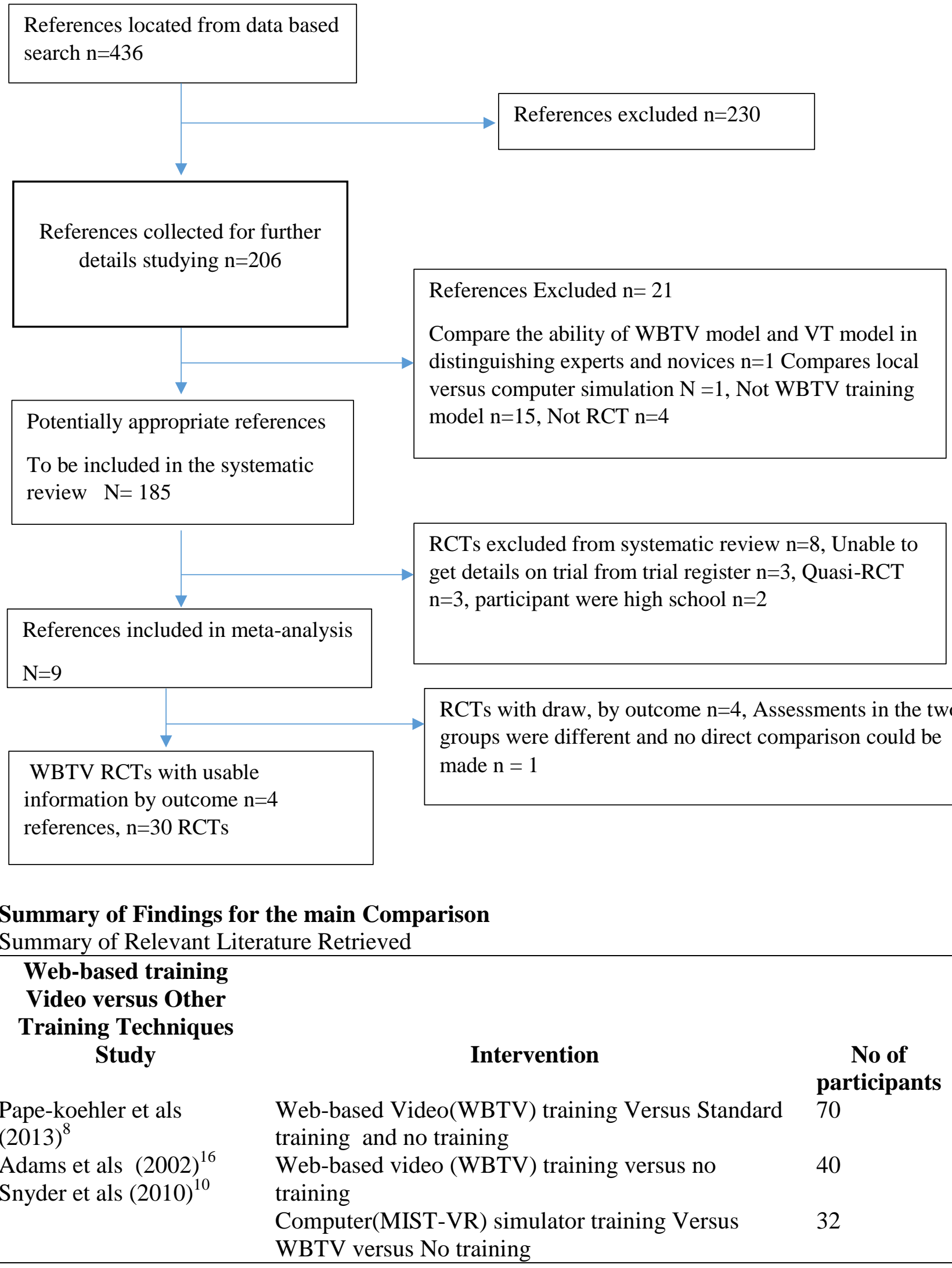




\section{Virtual reality stimulation Versus other training Techniques Study}

Ahlberg et al (2002) $)^{53}$ Ali et al (2002) ${ }^{54}$ Eversbusch and Grantcharov (2004) ${ }^{55}$

Gallagher et al (2002) ${ }^{21}$ Grantcharov et al $(2004)^{56}$

Hamilton et al (2002) $)^{35}$ Hyltander et al (2008) ${ }^{45}$ Jordan et al (2000)

Jordan et al (2001)

Kothari et al (2002) Lehmann et al (2005) Mackay et al (2002)

Munz et al (2004)

Pearson et al (2002)

Seymour et al (2002)

Torkington et al (2001)

Watterson et al (2002)

Wilhelm et al (2002) Youngblood et al (2005)

\section{Intervention}

Computer (MIST-VR) simulator training versus no training

Computer (MIST-VR) (medium level) versus computer (MIST-VR) simulator training (easy level Computer (GI Mentor II) versus no psychomotor training

Computer (MIST-VR) simulator training versus no training

Computer (MIST-VR) simulator training versus no 16 training

Computer (MIST-VR) simulator training versus video box simulator training Computer (LapSim) simulator training versus no training

Computer (MIST-VR) simulator training versus video box simulator training (randomly alternating image) versus video box simulator training (normal image)

Computer (MIST-VR) simulator training versus Zshaped or U-shaped maze video box simulator training versus no training Computer (MIST-VR) simulator training versus $\quad 32$ video box simulator training Computer (VEST) simulator training versus video 32 box simulator training Massed practice computer (MIST-VR) simulator training versus 2 types of distributed Computer (LapSim) simulator training versus video box simulator training versus no

Computer (MIST-VR) simulator training versus video box simulator training versus self-practice versus didactic instruction versus standard Computer (MIST-VR) simulator training versus standard training

Computer (MIST-VR) simulator training versus standard training versus no training Computer (URO Mentor) simulator training versus
Participant No 
standard training

Computer (URO Mentor) simulator training versus

standard training

Computer (LapSim) simulator training versus video 46

box simulator training versus no training

\section{FLS Video box Trainer}

Versus Techniques

Fried et al (1999)

Video box simulator training versus no training

12

Harold et al (2002)

Video box simulator training plus additional 17

Jordan et al (2000) instruction versus video box simulator

Jordan et al (2000)

Video box simulator training: randomly alternating 32

image versus $\mathrm{y}$-axis inverted image versus normal

image; versus simplified simulation (direct vision box training)

Keyser et al (2002)

Video box training versus simplified simulation 22

\section{(indirect vision mirrored box training}

Matsumoto et al (2002)

Video box simulator training versus model training versus standard training

Risucci et al (2001)

Video box simulator training plus additional instruction versus video box simulator

Scott et al (2000)

Video box simulator training versus no training

Taffinder et al (1998)

Video box simulator training versus no training

Traxer et al (2001)

Video box simulator training versus no training

\section{Results}

\section{Description of Studies}

A total of 436 references were identified through electronic searches of the Cochrane HepatoBiliary Group Controlled Trials Register and the Cochrane Central Register of Controlled Trials in The Cochrane Library $(n=78)$, Medline $(n=96)$, Embase $(n=72)$, Science Citation Index Expanded $(n=89)$ and other databases $(n=101)$. Fifty two duplicates and thirty clearly irrelevant references identified through reading abstracts were excluded. The remaining nineteenth references were retrieved for further assessment. No references were identified through scanning reference lists of the identified randomized trials. It was not possible to identify details concerning one trial identified from the trial register \{Pape-Koehler, 2013 \#419\}. No information was available from the authors of this trial, so it was excluded from the review. Twenty-six other references were excluded as they did not meet the inclusion criteria. In total, 8 trials were included. Two trials compare WBTV to no training, and standard training, one training compare it with VR and standard training with no training and with training. Seven trials compared VR and VT training, nine trials compared VR and no training or SLT; eight trials compared VR training, VT training and no training; and two trials compared different methods of VR training. Four trials compared VR training in surgical trainees with limited experience in laparoscopic surgery. Four trial compare VT to no training, five trials compare VT to standard training. Five did studies in WBTV did not state the experience of the participants. The other 
trials included medical students or surgical residents without any experience in laparoscopic surgery. Three trials that had adequate methodological quality in all four components were considered to have a low risk of bias. Details regarding the tasks in training and endpoint of training are recorded and classified as safety /efficacy study.

\section{Included Studies (8 Studies) WBTV}

Three RCTs and five non-RCTs investigating effectiveness of WBTV after watching Online surgical procedure for training laparoscopic cholecystectomy and endoscopy and were included in this review. Two studies investigated laparoscopic cholecystectomy procedures, and one studies investigated endoscopic procedures. Participants included general surgery and resident trainees.

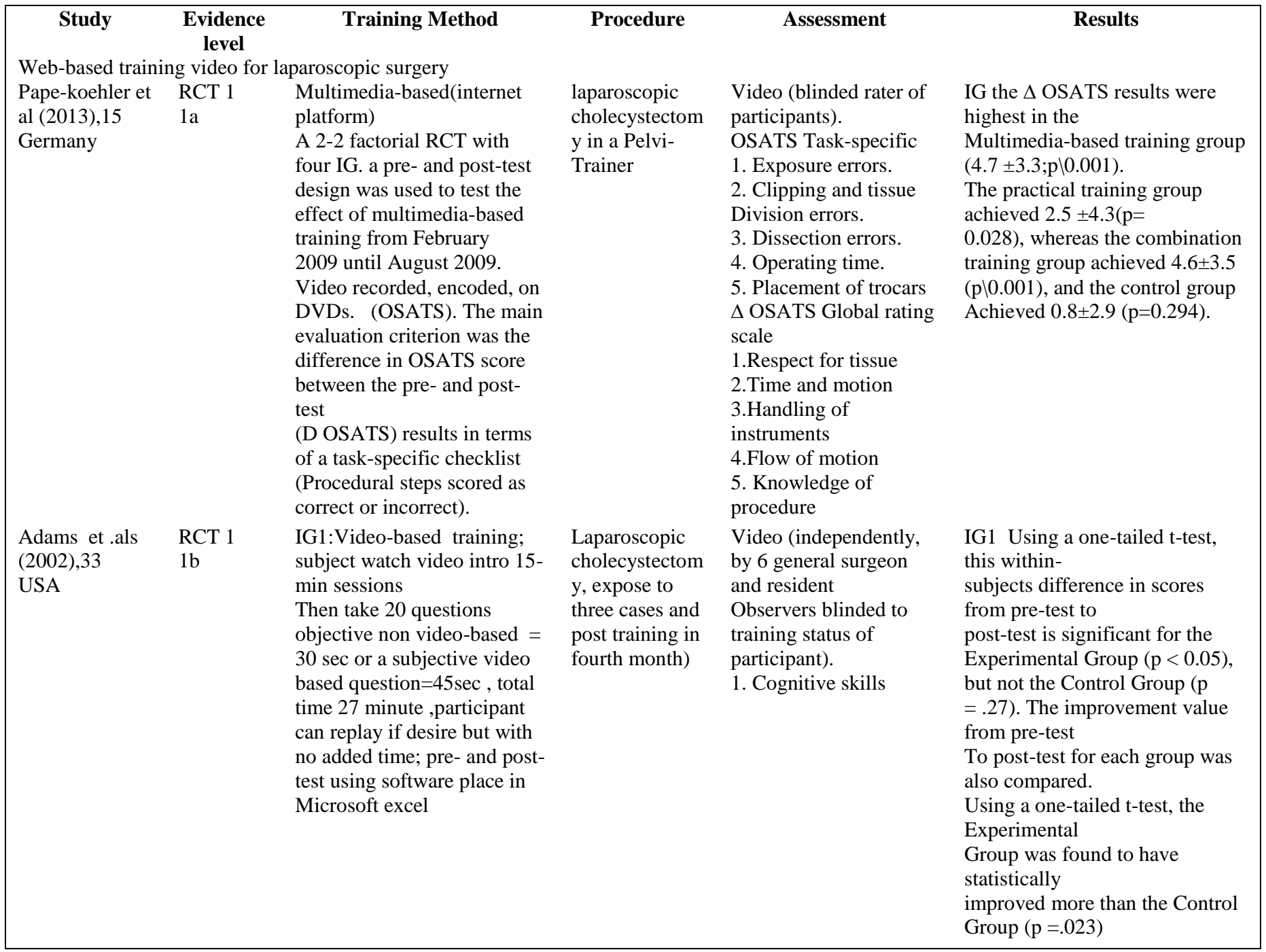




\begin{tabular}{|c|c|c|c|c|c|}
\hline $\begin{array}{l}\text { Snyder et. als } \\
(2010)^{10} \\
\text { USA }\end{array}$ & $\begin{array}{l}\text { RCT } 11 \\
2 \mathrm{c}\end{array}$ & $\begin{array}{l}\text { Medical students were } \\
\text { randomized to proficiency- } \\
\text { based training on VR } \\
\text { laparoscopy and endoscopy } \\
\text { simulators by two different } \\
\text { methods proctored training } \\
\text { (automated simulator } \\
\text { feedback plus human expert } \\
\text { feedback) or independent } \\
\text { training (simulator feedback } \\
\text { alone) }\end{array}$ & $\begin{array}{l}\text { tasks in a live } \\
\text { por- } \\
\text { Cine model. } \\
\text { Prior to their } \\
\text { entry into the } \\
\text { animal lab, all } \\
\text { trainees } \\
\text { watched an } \\
\text { instructional } \\
\text { video of the } \\
\text { procedure }\end{array}$ & $\begin{array}{l}\text { surgical performance } \\
\text { Virtual reality (VR) } \\
\text { surgical simulation and } \\
\text { Web-based multimedia } \\
\text { instruction are useful } \\
\text { Supplemental. }\end{array}$ & $\begin{array}{l}\text { Cox regression modelling with } \\
\text { adjustment for relevant } \\
\text { covariates demonstrated no } \\
\text { significant } \\
\text { difference in the likelihood of } \\
\text { successful task completion for } \\
\text { independent versus proctored } \\
\text { training [Hazard Ratio (HR) } \\
1.28 ; 95 \% \text { Confidence Interval } \\
\text { (CI) } 0.96-1.72 ; \mathrm{p}=0.09 \text { ]. } \\
\text { Trainees who observed the } \\
\text { actual procedure were more } \\
\text { likely } \\
\text { to be successful than those who } \\
\text { watched the instructional } \\
\text { Video alone (HR } 1.47 ; 95 \% \mathrm{CI} \\
1.09-1.98 ; \mathrm{p}=0.01 \text { ). }\end{array}$ \\
\hline
\end{tabular}

\begin{tabular}{|c|c|c|c|c|c|c|}
\hline Study & LOE & participant & Training Method & Procedure & Assessment & Result \\
\hline \multicolumn{7}{|c|}{ Comparison simulation training versus no simulation training } \\
\hline $\begin{array}{l}\text { Ahlberg et al } \\
(2007), 15 \\
\text { Sweden }\end{array}$ & RCT II & $\begin{array}{l}\mathrm{IG}=7, \mathrm{CG}=6 \text {, } \\
\text { surgical } \\
\text { residents } \\
\text { PGY 1-2 }\end{array}$ & $\begin{array}{l}\text { LapSim (without force } \\
\text { feedback) version } 2.0 \mathrm{VR} \\
\text { simulator: as many 1-h } \\
\text { supervised training } \\
\text { sessions } \\
\text { during } 1 \text { wk. (maximum } 8 \\
\text { per } \\
\text { day) as required to reach } \\
\text { proficiency levels on each } \\
\text { of the } 6 \text { examination tasks } \\
\text { at } \\
\text { Least twice. }\end{array}$ & $\begin{array}{l}\text { Laparoscopic } \\
\text { cholecystecto } \\
\text { my (assessed } \\
\text { first, fifth, and } \\
\text { tenth) }\end{array}$ & $\begin{array}{l}\text { Video ( } 2 \\
\text { observers } \\
\text { blinded to } \\
\text { training status } \\
\text { of participants). } \\
\text { 1. Exposure } \\
\text { errors. } \\
\text { 2. Clipping and } \\
\text { tissue } \\
\text { Division errors. } \\
\text { 3. Dissection } \\
\text { errors. } \\
\text { 4. Operating } \\
\text { time. }\end{array}$ & $\begin{array}{l}\text { IG fewer } \\
\text { intraoperative errors } \\
\text { for entire procedure } \\
\text { and separate portions } \\
\text { vs CG }(\mathrm{P}= \\
0.037) \text {. Exposure errors } \\
\text { reduced from } 53 \text { to } 15 \\
(\mathrm{P}=0.0402) \text {, clipping } \\
\text { and Tissue division } \\
\text { from } 7.1 \text { to } 1.9 \\
(\mathrm{P}<0.008) \text {, and } \\
\text { dissection from } 29.5 \text { to } \\
11.5(\mathrm{P}<0.03) . \\
\text { Operating time } \\
\text { reduced by } 58 \% \text { in } \mathrm{IG} \\
(\mathrm{P}=0.0586 \\
\mathrm{NS}) .\end{array}$ \\
\hline $\begin{array}{l}\text { Beyer et al } \\
(2011), 33 \\
\text { France }\end{array}$ & $\begin{array}{l}\text { Non- } \\
\text { RCT } \\
\text { III-3 }\end{array}$ & $\begin{array}{l}\text { IG1 }=6, \mathrm{IG} 2= \\
6, \mathrm{CG}=7, \\
\text { general surgery } \\
\text { or gynaecology } \\
\text { residents. }\end{array}$ & $\begin{array}{l}\text { IG1: FLS Training Box } \\
\text { simulator; proficiency- } \\
\text { based } \\
\text { training through } \\
\text { MISTELS } \\
\text { program, } 5 \text { tasks with } 5 \\
\text { individual } 60 \text {-min sessions } \\
\text { during a period of } 1 \text { mo.; } \\
\text { IG2: } \\
\text { LAP Mentor VR } \\
\text { simulator; } \\
\text { Organized in pairs } \\
\text { undergoing five } 120 \text {-min }\end{array}$ & $\begin{array}{l}\text { Dissection of } \\
\text { the vesicular } \\
\text { bed (assessed } \\
\text { retraining, } \\
\text { first month, } \\
\text { and post } \\
\text { Training in } \\
\text { fourth } \\
\text { month). }\end{array}$ & $\begin{array}{l}\text { Video } \\
\text { (independently, } \\
\text { by } 2 \\
\text { Observers } \\
\text { blinded to } \\
\text { training status } \\
\text { of participant). } \\
\text { 1. Depth } \\
\text { perception. } \\
\text { 2. Bimanual } \\
\text { dexterity. } \\
\text { 3. Efficiency. } \\
\text { 4. Tissue }\end{array}$ & $\begin{array}{l}\text { Improvement in } \\
\text { GOALS scores IG1 } \\
\text { (mean } 9.3 \text { vs } 12.4 ; \mathrm{P}= \\
0.04 \text { ) and } \\
\text { IG2 (mean } 9.2 \text { vs } 13.2 ; \\
\mathrm{P}=0.03 \text { ) } \\
\text { but not in CG in the } \\
\text { second } \\
\text { evaluation (12.2 vs } \\
11.7 \text {; } \\
\mathrm{P}=0.35 \text { ). Progression } \\
\text { score } \\
\text { higher in } \mathrm{IG} 1 \text { ( } \mathrm{P}=\end{array}$ \\
\hline
\end{tabular}




\begin{tabular}{|c|c|c|c|c|c|c|}
\hline & & & $\begin{array}{l}\text { sessions during a period of } \\
1 \text { mo. and participants } \\
\text { attempting all } 9 \text { basic } \\
\text { exercises, the } \\
\text { extracorporeal knot suture } \\
\text { exercise, and } \\
\text { cholecystectomy. }\end{array}$ & & $\begin{array}{l}\text { handling. } \\
\text { 5. Autonomy. }\end{array}$ & $\begin{array}{l}0.03) \text { and IG2 } \\
(\mathrm{P}=0.007) \text { vs } \mathrm{CG} . \\
\text { There was no } \\
\text { significant difference } \\
\text { between IG1 } \\
\text { And IG2 }(\mathrm{P}=0.28) .\end{array}$ \\
\hline $\begin{array}{l}\text { Cosman et al } \\
(2007), 16 \\
\text { Australia }\end{array}$ & RCT 11 & $\begin{array}{l}\mathrm{IG}=5, \mathrm{CG}=5 \text {, } \\
\text { volunteer basic } \\
\text { Surgical } \\
\text { trainees. }\end{array}$ & $\begin{array}{l}\text { LapSim (without haptic } \\
\text { feedback). Basic Skills } \\
\text { package version } 1.5 \mathrm{VR} \\
\text { Simulator; access for } \\
\text { maximum of } 1 \mathrm{~h} / \mathrm{d} \text { as } \\
\text { required to satisfy the } \\
\text { performance criteria on } 2 \\
\text { successive repetitions of } \\
\text { the clipping task. }\end{array}$ & $\begin{array}{l}\text { Clips } \\
\text { application } \\
\text { and division } \\
\text { of cystic } \\
\text { artery } \\
\text { (assessed } \\
\text { first) }\end{array}$ & $\begin{array}{l}\text { Video } \\
\text { (independently } \\
\text { by } 5 \\
\text { laparoscopic } \\
\text { surgeons } \\
\text { Blinded to } \\
\text { training status). } \\
\text { 1. Composite } \\
\text { error. score, } \\
6 \text { items } \\
\text { 2. Global rating } \\
\text { score. } \\
\text { 3. Operating } \\
\text { time. }\end{array}$ & $\begin{array}{l}\text { IG fewer } \\
\text { intraoperative errors } \\
\text { for the } \\
\text { entire procedure than } \\
\mathrm{CG} \text { (median } \\
10 \text { vs } 18 ; \mathrm{P}=0.05) . \mathrm{IG} \\
\text { better bimanual } \\
\text { coordination (mean } \\
3.0 \text { vs } 1.8 ; \mathrm{P}=0.05) \\
\text { and higher global } \\
\text { score (median } 3.2 \text { vs } \\
1.8 ;\end{array}$ \\
\hline $\begin{array}{l}\text { Grantcharov } \\
\text { et al } \\
\text { (2004),17 } \\
\text { Denmark }\end{array}$ & RCT II & $\begin{array}{l}\mathrm{IG}=8, \mathrm{CG}=8 \text {, } \\
\text { general surgical } \\
\text { Residents. }\end{array}$ & $\begin{array}{l}\text { MIST-VR simulator; fixed } \\
\text { number, } 10 \text { repetitions of } \\
6 \\
\text { abstract tasks of } \\
\text { progressive } \\
\text { complexity that are } \\
\text { designed } \\
\text { to simulate the techniques } \\
\text { used during laparoscopic } \\
\text { Cholecystectomy. }\end{array}$ & $\begin{array}{l}\text { Clips } \\
\text { application } \\
\text { and division } \\
\text { of cystic and } \\
\text { gallbladder } \\
\text { (assessed } \\
\text { second). }\end{array}$ & $\begin{array}{l}\text { Video } \\
\text { (independently } \\
\text { by } 2 \\
\text { surgeons } \\
\text { blinded to } \\
\text { Training } \\
\text { status). } \\
\text { 1. Operating } \\
\text { time. } \\
\text { 2. Errors (2 } \\
\text { items). } \\
3 . \text { Economy of } \\
\text { movements } \\
\text { ( } 2 \text { items). }\end{array}$ & $\begin{array}{l}\text { Operating time } \\
\text { reduced in IG } \\
\text { compared with the } \\
\mathrm{CG} \mathrm{P}=0.04) \text { than } \mathrm{CG} \text {. } \\
\text { Procedure } \\
\text { time reduced from } 172 \\
\text { to } 94 \mathrm{~s} \\
(46 \%) \text { in } \mathrm{IG}(\mathrm{P}= \\
0.075) .(\mathrm{P}=0.021) . \mathrm{IG} \\
\text { greater } \\
\text { Improvement in } \\
\text { intraoperative errors }(\mathrm{P} \\
=0.003) \text { and economy } \\
\text { of movement }(\mathrm{P}= \\
0.003) \text { scores than } \mathrm{CG}\end{array}$ \\
\hline $\begin{array}{l}\text { Hogle et al } \\
\text { (2009), } 18 \\
\text { United States } \\
\text { (only Study } \\
\text { 1) }\end{array}$ & RCT II & $\begin{array}{l}\mathrm{IG}=6, \mathrm{CG}=6 \text {, } \\
\text { surgical } \\
\text { residents } \\
\text { PGY 1 }\end{array}$ & $\begin{array}{l}\text { LapSim VR simulator; } 2 \\
\text { simulation training } \\
\text { sessions } \\
\text { per week until level } 3 \\
\text { passed } \\
\text { for each task: camera } \\
\text { navigation, instrument } \\
\text { navigation, coordination, } \\
\text { grasping, lifting and } \\
\text { grasping, cutting, and clip } \\
\text { Applying. }\end{array}$ & $\begin{array}{l}\text { Laparoscopic } \\
\text { Cholecystecto } \\
\text { my (assessed } \\
2 \\
\text { Consecutive). }\end{array}$ & $\begin{array}{l}\text { Video; } \\
\text { combined } \\
\text { GOALS } \\
\text { scores from } \\
\text { supervising } \\
\text { surgeon and } \\
\text { reviewers } \\
\text { blinded to } \\
\text { training status } \\
\text { of } \\
\text { Participants. }\end{array}$ & $\begin{array}{l}\text { No significant } \\
\text { difference between IG } \\
\text { and CG in the } 5 \\
\text { GOALS domains: } \\
\text { depth perception } \\
\text { (mean } 3.6 \text { vs } \\
3.35 ; \mathrm{P}=0.99 \text { ), } \\
\text { bimanual } \\
\text { dexterity (mean } 3.17 \\
\text { vs } 2.90 ; \\
\mathrm{P}=0.55 \text { ), efficiency } \\
\text { (mean } 2.89 \\
\text { vs } 2.82 ; \mathrm{P}=0.93 \text { ), } \\
\text { tissue handling } \\
\text { (mean } 2.96 \text { vs } 3.10 ; \mathrm{P} \\
=0.56 \text { ), } \\
\text { autonomy (mean } 3.23 \\
\text { vs } 3.11 ; \\
\mathrm{P}=0.85 \text { ). }\end{array}$ \\
\hline
\end{tabular}


DOI: 10.5281/zenodo.1043362

\begin{tabular}{|c|c|c|c|c|c|c|}
\hline $\begin{array}{l}\text { Scott et al } \\
(2000), 19 \\
\text { United State }\end{array}$ & RCT II & $\begin{array}{l}\text { IG }=13, \mathrm{CG}= \\
9, \\
\text { general surgical } \\
\text { Residents PGY } \\
1 \text { or } 2-\text { on } 1-\mathrm{mo} \\
\text { rotation. }\end{array}$ & $\begin{array}{l}\text { SCMIS GEM video- } \\
\text { trainer; } \\
\text { during weeks } 2 \text { and } 3 \text {, } \\
\text { residents met for at least } \\
30 \\
\text { min a day for } 10 \text { d to } \\
\text { perform } \\
\text { the } 5 \text { established } \\
\text { laparoscopic drills on a } \\
\text { video } \\
\text { trainer: bean drop, running } \\
\text { string, checkerboard, } \\
\text { block } \\
\text { Move, and suture foam. }\end{array}$ & $\begin{array}{l}\text { Laparoscopic } \\
\text { Cholecystecto } \\
\text { my (assessed } \\
\text { pertaining and } \\
\text { post training } \\
\text { performed } \\
\text { with same } \\
\text { assistant } \\
\text { surgeon). }\end{array}$ & $\begin{array}{l}\text { Direct } \\
\text { observation by } \\
3 \\
\text { Surgeons } \\
\text { blinded to } \\
\text { training status; } \\
8 \text { criteria } \\
\text { assessed. }\end{array}$ & $\begin{array}{l}\text { Improved scores for } \\
\text { IG compared } \\
\text { with CG in } 4 \text { of } 8 \\
\text { performance criteria: } \\
\text { respect for tissue( } \mathrm{P}= \\
0.035) \text {, instrument } \\
\text { handling } \\
(\mathrm{P}=0.005) \text {, use of } \\
\text { assistants ( } \mathrm{P}=0.035) \text {, } \\
\text { overall performance (P } \\
=0.007) \text {. No } \\
\text { significant difference } \\
\text { Between IG and CG } \\
\text { for time and motion, } \\
\text { knowledge of } \\
\text { instruments, flow of } \\
\text { operation, and } \\
\text { knowledge of specific } \\
\text { procedure. } \\
\text { Performance } \\
\text { improvement defined } \\
\text { as baseline minus post } \\
\text { training score, } \\
\text { adjusted } \\
\text { For differences in } \\
\text { baseline scores. }\end{array}$ \\
\hline
\end{tabular}

\section{Discussion}

\section{Outcomes}

A total of 30 trials involving 766 participants were included in this review. As mentioned in the protocol, the results were reported separately for trainees with no laparoscopic experience and those with laparoscopic experience (such as performing laparoscopic procedures under supervision). The results are summarized in the table above. 3 trial mentioned patient-related outcome (cognitive skills which are factual). None of the remaining trials that used animals or humans to assess the outcomes reported animal or patient morbidity or mortality.

\section{Description of Studies}

Web-based Training for Laparoscopic Surgery- WBTV training plus standard practical training. To gain a more complete understanding of all of the significant predictors that contribute to score improvement, and to once again verify the significance of video repetition, by using stepwise linear regression analysis. This analysis showed that educational level, previous LC experience, and training program version are the only significant predictors of improvement. OSATS Taskspecific was use to assess, exposure errors. Clipping and tissue division errors, dissection errors. Operating time. Placement of trocars, $\triangle$ OSATS Global rating scale. Respect for tissue, time and motion, handling of instruments, flow of motion, thus Knowledge of procedure Improvement increases with decreasing educational level, increasing LC experience, and the experimental version T-tests and a linear regression model reveal the significance of program aspects, especially the video repetition feature. Conclusions based on the data set are valid due to the equivalency of the test banks and subject samples. Although this is a pilot version of the program, testing has revealed the significance of the training methods used. This significance justifies further evaluation of the pilot program as well as development of enhanced iterations. 


\section{Laparoscopic Experience with Practice Training (SLT)}

WBTV versus standard training Time taken to perform the job or speed with which the job was completed The meta-analysis showed that there was no statistically, significant difference in the time taken to complete the task (SMD $-0 \cdot 06,95$ per cent c. $-0 \cdot 40$ to $0 \cdot 52$ ), reduction in the time taken to complete the task after compared with before training (SMD -0.61, 95 per cent c.i. $-1 \cdot 51$ to $0 \cdot 29$ ), speed in performing the tasks between WBTV and SLT (SMD $-0 \cdot 33,95$ per cent c.i. -0.95 to 0.28 ), or in the change in speed in either hand in performing the task. Hence WBTV is more effective compare to practical training alone without watching a multimedia laparoscopic video that help to develop cognitive skills.

\section{Error Score}

There was no difference in error scores between the two groups. The error score was assessed by dropping the object, perforation of the object, or by composite error score from the computer.

\section{WBTV training for laparoscopic Surgery plus SLT with a pelvic -trainer model}

The laparoscopic cholecystectomy computer-based training program developed here has the potential to change medical education dramatically. Combined with the technical skill trainers already widely available, this program can teach the anatomical structure recognition skills that can only be gained through experience of watching actual surgeries.

\section{WBTV versus VR Simulation}

Surgical training programs may not need to devote time and effort to provide expert feedback during proficiency-based VR simulator training, as long as the proficiency criteria are available and clear. Surgical trainees should recognize that while instructional videos and VR training are useful resources, they do not appear to be adequate substitutes for observation of complex procedures. Observing surgical procedures, in the context of deliberate practice and directed hands-on training, remains a valuable learning experience, even when the operator is a relatively unskilled trainee. Further studies of this topic should be performed in junior surgical residents to validate these conclusions.

Computer simulation showed mixed results, superior in some studies, but not others and was inferior to video simulation in one study. This may have depended on types of tasks, with computer simulation producing better results for tasks such as incisions, but not for knot tying times. However, there were too few studies to determine this.

\section{WBTV versus No Training}

WBTV groups did not show consistently better results than groups who did not receive training.

\section{Conclusion}

Generally, no clear differences were seen between WBTV and other forms of training such as bench models or standard training. However there are better assessment tool that can show the various benefit - SimpraxisTM Laparoscopic Cholecystectomy Trainer. Since each teaching technique have different function and task, it would be significant to study on how; combined piece of a surgical training method should have both technical and nontechnical skills acquisition 
abilities also a better outcome, accessibilities. WBTV is cheap, accessible, but the educational value is unknown because there are few publications written about the effectiveness.

\section{References}

[1] Singh P, Darzi A. Surgical training. British Journal of Surgery. 2013;100(s6):19-21.

[2] J. Scott Rankin M. William Stewart Halsted. Annals of Surgery 2006;243: 418-425); Volume 243, ( Number 3, March 2006).

[3] Daniel J. Scott MD, *,2 Juan C. Cendan, M.D.,† Carla M. Pugh, M.D., Ph.D.,ł Rebecca M. Minter, M.D.,§, Gary L. Dunnington MD, II and Rosemary A. Kozar, M.D., Ph.D. The Changing Face of Surgical Education: Simulation as the New Paradigm1. Journal of Surgical Research. January 7, 2008 2008; Journal of Surgical Research 147, 189-193 (2008.

[4] Babineau TJ, Becker J, Gibbons G, et al. The "cost" of operative training for surgical residents. Archives of surgery (Chicago, Ill. : 1960). Apr 2004;139(4):366-369; discussion 369-370.

[5] Lance R. Farnworth MD, David E. Lemay MD, Todd Wooldridge BS, et al. A Comparison Of Operative Times In Arthroscopic Acl Reconstruction Between Orthopaedic Faculty and Residents; The Financial Impact Of Orthopaeddic Surgical Training In The Opearting Room

[6] Tekkis PP, Fazio VW, Lavery IC, et al. Evaluation of the Learning Curve in Ileal Pouch???Anal Anastomosis Surgery. Annals of Surgery. 2005;241(2):262-268.

[7] Herrell SD, Smith Jr JA. Robotic-assisted laparoscopic prostatectomy: What is the learning curve? Urology. 11// 2005;66(5, Supplement):105-107.

[8] Pape-Koehler C, Immenroth M, Sauerland S, et al. Multimedia-based training on Internet platforms improves surgical performance: a randomized controlled trial. Surgical Endoscopy. 2013/05/01 2013;27(5):1737-1747.

[9] Brinke Bt, Klitsie PJ, Timman R, Busschbach JJV, Lange JF, Kleinrensink G-J. Anatomy Education and Classroom Versus Laparoscopic Dissection-Based Training: A Randomized Study at One Medical School. Academic Medicine. 9000; Publish Ahead of Print:10.1097/ACM.0000000000000223.

[10] Hawn CWSMJVSLYJRPjRHCMT. Effect of Virtual Reality Simulator Training Method and Observational Learning on Surgical Performance. World Journal of Surgery. 2010;35:245252.

[11] Munz Y, Kumar BD, Moorthy K, Bann S, Darzi A. Laparoscopic virtual reality and box trainers: is one superior to the other? Surg Endosc. Mar 2004;18(3):485-494.

[12] Didier Mutter MV, Bernard Dallemagne, Silvana Perretta, Joël Leroy and Jacques Marescaux. WeBSurg: An Innovative Educational Web Site in Minimally Invasive Surgery--Principles and Results. Surgical Innovation. 7 March 2011;SURG INNOV 2011 18: 8.

[13] HENK W. R. SCHREUDER1 GO, MARIO MAAS3, JAN C. C. BORLEFFS4 \& MARLIES P. SCHIJVEN. Implementation of simulation in surgical practice: Minimally invasive surgery hastaken the lead: The Dutch experience. Medical teacher. 2011;33: 105-115(2011; 33: 105115).

[14] Sarah K. Tolerton B, , , Thomas J. Hugh M, †,, Peter H. Cosman P, MBiostats, FRACS $\ddagger$. The Production of Audiovisual Teaching Tools in Minimally Invasive Surgery. Journal of surgical education. May-June 2012 2012; Volume 69, , (Issue 3,):Pages 404-406.

[15] Fraser L, Gunasekaran S, Mistry D, Ward VM. Current use of and attitudes to e-learning in otolaryngology: questionnaire survey of UK otolaryngology trainees. The Journal of laryngology and otology. Apr 2011;125(4):338-342.

[16] Reid Adams KBG, Maranda. s. VIDEO-BASED TRAINING FOR LAPAROSCOPIC SURGERY. 2002.

[17] Carla M. Pugh M, PhD, Andrew watson, MD, Richard H. Bell, Jr, MD Surgical Education in the Internet Era. Surgical Research 2009(156).

[18] (internet) M. Multimedia (Internet) Retrieve 2012. 
[19] Lucas S, Tuncel A, Bensalah K, et al. Virtual reality training improves simulated laparoscopic surgery performance in laparoscopy naïve medical students. Journal of Endourology. 2008;22(5):1047-1051.

[20] NagendranM GK, Aggarwal R, LoizidouM, Davidson BR. Virtual reality training for surgical trainees in laparoscopic surgery (Review).

[21] Gallagher AG, Satava RM. Virtual reality as a metric for the assessment of laparoscopic psychomotor skills: Learning curves and reliability measures. Surgical Endoscopy and Other Interventional Techniques. 2002;16(12):1746-1752.

[22] Aggarwal R, Ward J, Balasundaram I, Sains P, Athanasiou T, Darzi A. Proving the effectiveness of virtual reality simulation for training in laparoscopic surgery. Annals of Surgery. 2007;246(5):771-779.

[23] Fried GM, Feldman LS, Vassiliou MC, et al. Proving the Value of Simulation in Laparoscopic Surgery. Annals of Surgery. 2004;240(3):518-528.

[24] Farnworth LR, Lemay DE, Wooldridge T, et al. A comparison of operative times in arthroscopic ACL reconstruction between orthopaedic faculty and residents: the financial impact of orthopaedic surgical training in the operating room. The Iowa orthopaedic journal. 2001;21:3135.

[25] Autry AM, Knight S, Lester F, et al. Teaching surgical skills using video internet communication in a resource-limited setting. Obstetrics and Gynecology. 2013;122(1):127-131.

[26] Moorthy K, Munz Y, Jiwanji M, Bann S, Chang A, Darzi A. Validity and reliability of a virtual reality upper gastrointestinal simulator and cross validation using structured assessment of individual performance with video playback. Surg Endosc. Feb 2004;18(2):328-333.

[27] Dawe SR, Windsor JA, Broeders JAJL, Cregan PC, Hewett PJ, Maddern GJ. A systematic review of surgical skills transfer after simulation-based training: Laparoscopic cholecystectomy and endoscopy. Annals of Surgery. 2014;259(2):236-248.

[28] Sturm LP, Windsor JA, Cosman PH, Cregan P, Hewett PJ, Maddern GJ. A systematic review of skills transfer after surgical simulation training. Annals of Surgery. 2008;248(2):166-179.

[29] Gurusamy K, Aggarwal R, Palanivelu L, Davidson BR. Systematic review of randomized controlled trials on the effectiveness of virtual reality training for laparoscopic surgery. British Journal of Surgery. 2008;95(9):1088-1097.

[30] Gravante G, Venditti D. A Systematic review on low-cost box models to achieve basic and advanced laparoscopic skills during modern surgical training. Surgical Laparoscopy, Endoscopy and Percutaneous Techniques. 2013;23(2):109-120.

[31] Kneebone R, ApSimon D. Surgical skills training: Simulation and multimedia combined. Medical Education. 2001;35(9):909-915.

[32] Zendejas B, Cook DA, Bingener J, et al. Simulation-based mastery learning improves patient outcomes in laparoscopic inguinal hernia repair: A randomized controlled trial. Annals of Surgery. 2011;254(3):502-511.

[33] Gallagher AG, Traynor O. Simulation in surgery: opportunity or threat? Irish J. Med. Sci. Dec 2008;177(4):283-287.

[34] Rege RV. Commentary on: "Cost: The missing outcome in simulation-based education research: A systematic review" by Zendejas et al. Surgery.153(2):177-178.

[35] Hamilton EC, Scott DJ, Fleming JB, et al. Comparison of video trainer and virtual reality training systems on acquisition of laparoscopic skills. Surgical Endoscopy And Other Interventional Techniques. 2002/03/01 2002;16(3):406-411.

[36] Gurusamy KS N, Toon CD, Davidson BR. Laparoscopic surgical boxmodel training for surgical trainees with limited prior laparoscopic experience (Review).

[37] Gurusamy KS, Nagendran M, Toon CD, Davidson BR. Laparoscopic surgical box model training for surgical trainees with limited prior laparoscopic experience. The Cochrane database of systematic reviews. 2014;3:Cd010478. 
[38] Vassiliou MC, Dunkin BJ, Marks JM, Fried GM. FLS and FES: comprehensive models of training and assessment. The Surgical clinics of North America. Jun 2010;90(3):535-558.

[39] McCluney AL, Vassiliou MC, Kaneva PA, et al. FLS simulator performance predicts intraoperative laparoscopic skill. Surgical Endoscopy. 2007/11/01 2007;21(11):1991-1995.

[40] Aggarwal R, Moorthy K, Darzi A. Laparoscopic skills training and assessment. British Journal of Surgery. 2004;91(12):1549-1558.

[41] Surgeons. S--TSoAGaE. SAGES 2014 Exhibiting Companies. 42. Chair: Steven D. Schwaitzberg MC-CLMB, MD. SAGES Postgraduate Courses: Laparoscopic Cholecystectomy: Best Practices for Optimizing Clinical Outcomes.

[42] Sutherland LM, Middleton PF, Anthony A, et al. Surgical simulation: A systematic review. Annals of Surgery. 2006;243(3):291-300.

[43] Tolerton SK, Hugh TJ, Cosman PH. The Production of Audiovisual Teaching Tools in Minimally Invasive Surgery. Journal of surgical education. 5// 2012;69(3):404-406.

[44] Seymour N. VR to OR: A Review of the Evidence that Virtual Reality Simulation Improves Operating Room Performance. World Journal of Surgery. 2008/02/01 2008;32(2):182-188.

[45] Soares MM, Jacobs K, Zhang L, et al. The added value of virtual reality technology and force feedback for surgical training simulators. Work. 2012;41:2288-2292.

[46] Palter VN, Grantcharov TP. Individualized deliberate practice on a virtual reality simulator improves technical performance of surgical novices in the operating room: A randomized controlled trial. Annals of Surgery. 2014;259(3):443-448.

[47] Vanessa N. Palter MD TPGMP. Simulation in surgical education. CMAJ. AUGUST 10, 20.

[48] Waugh PRaN. A simplified search strategy for identifying randomised controlled trials for systematic reviews of health care interventions: a comparison with more exhaustive strategies. BMC Med Res Methodol. 2005; 5: 23. 2005.

[49] Higgins JP, Green S. Cochrane Handbook for Systematic Reviews of Interventions: Cochrane Book Series. John Wiley and Sons; 2008.

[50] NHMRC. NHMRC additional levels of evidence and grades for recommendations for developers of guidelines. 2009.

[51] Evans D. Hierarchy of evidence: a framework for ranking evidence evaluating healthcare interventions. Journal of Clinical Nursing. 2003;12(1):77-84.

[52] Ahlberg G, Heikkinen T, Iselius L, Leijonmarck CE, Rutqvist J, Arvidsson D. Does training in a virtual reality simulator improve surgical performance? Surgical Endoscopy and Other Interventional Techniques. 2002;16(1):126-129.

[53] Ali MR, Mowery Y, Kaplan B, DeMaria EJ. Training the novice in laparoscopy: More challenge is better. Surgical Endoscopy and Other Interventional Techniques. 2002;16(12):1732-1736.

[54] Eversbusch A, Grantcharov TP. Learning curves and impact of psychomotor training on performance in simulated colonoscopy: a randomized trial using a virtual reality endoscopy trainer. Surgical Endoscopy And Other Interventional Techniques. 2004/10/01 2004;18(10):15141518.

[55] Grantcharov TP, Kristiansen VB, Bendix J, Bardram L, Rosenberg J, Funch-Jensen P. Randomized clinical trial of virtual reality simulation for laparoscopic skills training. British Journal of Surgery. 2004;91(2):146-150.

*Corresponding author.

E-mail address: alfred.egedovo@ my.jcu.edu.au 